\title{
Bonding to Bridging: Networking Patterns of Up-country Tamil Businesses in Sri Lanka
}

\section{Sarath Ananda}

Dept. of Social Sciences, Faculty of Social Sciences and Languages, Sabaragamuwa University of Sri Lanka, P.O.Box 02, Belihuloya, Sri Lanka.sarath_a@yahoo.com

\begin{abstract}
The entrepreneurial role of Up-country Tamils is significant among the other Tamil groups as representative of "entrepreneurial little tradition" in the Sri Lankan commercial sector. Since they commit three-fold characteristics of ethnicentrepreneurship, which are being members of a marginal, minority and immigrant group, the study is intended to contribute to the construction of a broader discourse on the particular characteristics of Up-country Tamil entrepreneurship in Sri Lanka. Multiple factors such as historical protocol, politico-economic background and cultural causes are responsible for construction of their entrepreneurial identity. The caste and kinship-based networking pattern and excessive self exploitation help them to construct the initial social capital. However, when the entrepreneur either seeks to widen the entrepreneurial capacity or when the entrepreneur is unsatisfied with the basic form of networking, he/she is required to shift from privet spaces to public spaces. In one hand it is a geographical movement from the estate sector to a public location such as a town or a bazaar. On the other hand it tends to be a modernization of traditional norms and values of the Tamil community. Therefore, this study may be a source of general understanding of a marginal social group overcomes its sociocultural barriers in terms of entrepreneurship development; it also attempts to reveal the cultural structure of the Up-country Tamil community, their everyday needs, and the interrelations between members to achieve goals. Within this ground, this study attempts to describe significant entrepreneurial patterns of Up-country Tamil community by field research conducted in three major plantation areas in Sri Lanka.
\end{abstract}

Key Words: Up-country Tamils, Entrepreneurship, Networking Patterns

\section{Introduction}

The contribution of ethnic Up-country Tamils to the Sri Lankan commercial sector through various business activities has been momentous. Their entrepreneurial role is significant, particularly in retail and wholesale grocery (food stuff) business, hardware businesses, pawn broking, jewellery, textile industry and Siva cafes etc. Despite being a minority immigrant ethnic group, 
they have shown aptitude for trade even with the prevalence of Sinhalese national hegemony, ancestral pride of Jaffna Tamils, and the business authority of ethnic Muslims in the Island. Most Up-country Tamils live in central high lands of Sri Lanka, yet others are also found in major urban areas and in the Northern and Eastern provinces. They are descendants of the workercommunity which migrated from South India to Sri Lanka in the $19^{\text {th }}$ and $20^{\text {th }}$ centuries to work in coffee, tea and rubber plantations as a result of historical expansion of colonial plantation economy in the subordinate periphery (De Silva 2005, Kodikara 1965, Venden 1997). Some also migrated on their own as merchants and other service providers. At present, a considerable number of Up-country Tamil individuals have succeeded in transforming their traditional social status by engaging in trade related activities. During the recent decades they have become economically successful in the towns of Central Province, and later have expanded their commercial activities to Colombo, becoming dominant in retail trade. By the early stage of the $1980 \mathrm{~s}$, they were able to successfully control almost $60 \%$ of shops in the central market in Pettah, Colombo. (Hollup 1994) Although methodological issues exist about the surveying of the ethnic composition of the business sector, it does not obstruct one from observing the high contribution by the Up-country Tamils to the business activities in Colombo, the commercial hub of Sri Lanka.

Before the nature of their entrepreneurship is investigated, some knowledge on the historical and social background of Up-country Tamils is required as an approach to the main context. Historical incidents faced by them and the structural factors that exist in their community have directly affected their entrepreneurial accomplishments. When observed carefully, their entrepreneurial emergence seems to have derived from two essential streams of individuals. The first group basically consists of Kanganies who arrived as the overseers of labourers with the establishment of the colonial plantation system (Moldrich 1988,). In addition, the vendors who came from India targeting the same labourer community and Kanakkupulles who were knowledgeable in book keeping and check-roll maintenance also can be included into the same category. The second group who has been stabilized as traders seems to have been drawn from general labour community as a result of their long standing endeavour to gain the current attainments.

As the representatives of the middle order of the South Indian caste hierarchy, some status groups such as Wellalans, Kallans and Maravars succeeded in receiving advance positions as overseers or Kanganies in the British plantation system of Ceylon (Moldrich 1988, Wesumperuma 1986). With these elevated positions they had more opportunities to gain external relationships and awareness to control the rest of their community. As an extension of the process, they have succeeded in building up their political power after the introduction of universal suffragette to the constitution and accumulate capital as the labour 
suppliers to the plantation sector. It seems that the Kanganies particularly had a wide advantage to rise as the dominant moneylenders in terms of the capability of control over their own kind (Heidamann 1992, Wesumperuma 1986). Moreover, the formation of their privileged social status, gave them opportunity to accumulate social capital through the external relationships. Some who came directly from India as vendors concurrently happened to be derived from the same upper level castes. Despite the fact that Kanakkupulleis have not obtained much attention from writers and scholars so far, they also can be considered as another significant group of Tamil emigrants who gradually invaded the business sector. The Kanakkupulleis who departed from estates due to various reasons were easily able to find jobs as accountants of shops in nearby towns and bazaars, and later on entered into the self owned business activities. They had accumulated enough human capital from both long term trainings as book keepers or check-roll handlers of the estates, and business knowledge extracted from new occupations. However, the endeavour to enter into the business sector was much more difficult to the common workers who belonged to the lowest ranks of the plantation sector. Therefore, this long standing circumstance of the plantation sector should be understood only after proper investigation of socio-economic and historical factors related to the Up-country Tamil community.

Studying the networking, social ties and bridging through caste, kinship, marriage, neighbourhood, and/or friendship would be important to understand the peculiar nature of their ethnic businesses. In addition to the primordial social factors, there are significant trends of entrepreneurship emerging within the Up-country Tamil community as a result of their reaction to the internal and external social burdens and opportunities. For instance, the influence of traditional social values, impact of current global economic trends, the political motives to build their own identity among other ethnic groups, economic corporation of governmental and non-governmental organizations, reaction to unemployment or underemployment and loss of social security within plantation economy due to various structural adjustment policies are leading factors among them.

The entrepreneurial mobility of bottom level of the Up-country Tamils shows particular characteristics of 'little tradition'. Basically the initiation of a business from micro level is greatly dependent on the level of endurance and unlimited dedication of the entrepreneur. For instance, a good number of "Tamil businesses" in Sri Lanka were born out of humble beginnings such as collecting old news papers, used bottles, and scrapped metals from surrounding Sinhalese villages. These items were recycled into useful products. These types of businesses are known as income generating activities that are less profitable and highly labour consuming. Besides, such businesses were disliked by traditional Sinhalese who saw them as "third class businesses". 
However the initial micro level capitals that were accumulated from such low level businesses were reinvested successfully into a better business at the second stage. The biographies of many Tamil businessmen are elaborated by such hard work and self exploiting history. Therefore, the main objective of this paper is investigating the social accumulating patterns by Up-country Tamils on their entrepreneurial purposes.

\section{Theoretical Perspective}

The concept of bonding and bridging which has been developed under the theme of social capital is one way of examining the Up-country Tamil entrepreneurship. These social ties and their economic functions have been discussed among academics remarkably in the contemporary period. Woolcock \& Deepa (2000), Granovetter (1973) and Putnam (2000) use the concepts "bonding" and "bridging" to explain the initial situation and the advanced stages of networking process in terms of enhancing entrepreneurial capacity of the Up-country Tamil in the society. The concept is significant when explaining particular types networking patterns that exist in societies which have primitive social relations. For instance, primitive ties such as caste, kinship, neighbourhood, or family would affect the individual as bonds stagnating social life while, breaking of these identical bonds or initial social ties could be used in bridging of intra community networks as productive elements in the development process. Bridge et al. (2009) classify the diversity of these concepts stating that, bonding social capital associated with strong bonds acts as a 'social glue', while bridging social capital characterized by "weaker and less dense but more cross-cutting ties" proceeds to be 'social oil' to the individual. The authors also state that one more dimension of social capital is formed through linkages with various social status and power groups such as politicians and influential figures in the civil society. However it is preferable to take this third dimension as an extension of the bonded relations for the purpose of this study.

At the initial stages, the micro-level or small-scale entrepreneurs highly depend on their bonding with kin and kith, neighbours or friends for support credit and insurance. The extra-community bridging is important to the prospective entrepreneur as they cease primitive levels of business for further expansion of trade. However, there can be both negative and positive outcomes of such social ties. For instance, when extra-community networks (bridging) and intra-community networks are low, it may be causing the decline of social capital. High levels of bridging and low ranks of bonding may cause ruralurban migration or breakthrough from the initial stage of entrepreneur-ship. However, poor villagers constantly illustrate the opposite of above situation; low bridging and high bonding. Successful entrepreneurs are capable in enhancing of both these factors in very high levels (Woolcook \& Deepa 2000). 
The concept of bonding and bridging is used by the same writers to examine the well-known 'Grameen Bank' model in Bangladesh, where poor village women successfully carry out their small businesses through non-material collateral loans on the basis of their membership in a small group. They use five stages to explain the bonding and bridging circumstances of the poor village community as they moved from defence condition to offence in their business activities (Ibid). Usually, the Grameen Bank model of Bangladesh is known as a well organized welfare and micro-credit based development programme; but the concept of bonding and bridging is also applicable when investigating informal level marginal or minority businesses. In-group ties that are embedded in the community provide strong social security in the initial stages of micro and small-scale enterprises. These strong in-group relations have been the subject of social network literature of the classical sociologists such as Lazarsfeld \& Merton (1954), Simmel (1971), and Park \& Burgess (1921). They used the term homophily ${ }^{1}$ to explain the particular characteristics of the gathering of similar kinds.

In addition, the concept of entrepreneurship has been used to develop theoretical perspective of paper. This concept has been a topic of academic and philosophical discussion amongst economists, sociologists and psychologists (McClelland \& Winter 1971, Wilken 1979). Even though the early participants in the discussions did not use the term 'entrepreneurship', they attempted to accurately define it and interpret its characteristics ${ }^{2}$. While these ideas were important to get a general idea of entrepreneurship, notions of Hoselitz (1951) , Marries and Somerset (1971), Wilken (1979) seem to be still valid in terms of identifying peculiar characteristics of marginal entrepreneurship. Hoselitz (1951) provide theoretical constructs in the context of social marginality focusing on the impotency of social groups rather than individual economic agents $^{3}$. In contrast to an emphasis on marginality, there is also emphasis upon the necessity to some degree of social integration and cohesion within the marginalized group if entrepreneurship is to succeed. This factor emphasizes the need for some integrative bonds between entrepreneurs and the larger social system. Marries and Somerset (1971) have emphasized this factor, claiming that an increase in the scale or range of interaction is necessary and that barriers to interaction must be broken down if entrepreneurship is to occur. Group solidarity and resources at hand are also crucial factors dealing with entrepreneurship. According to Wilken (1979) social marginality is determined by social-isolation, for instance, being an immigrant and being a member of a minority group are the fundamentals of marginal entrepreneurship. It considers the space of access to the mobility channel within marginality is inevitable in definition ${ }^{4}$. Therefore, these notional approaches have been used as the basic framework of this study. 


\section{Methodology}

In order to achieve the main aim of the Study, the sample selection is based on following characteristics: (1) the most concentrated area in terms of historical dissemination of tea plantation sector in Sri Lanka, (2) one of the areas highly populated by Up-country Tamil community, and (3) comparatively higher concentration of Up-country Tamils in terms of existing business activities. Therefore, three major towns such as Nuwara Eliya, Badulla and Hatton which are highly populated by Up-country Tamils were selected as the research field. These three areas belong to Nuwara Eliya and Badulla districts in Sri Lanka.

The sample of entrepreneurs selected for the Study, consists of 76 micro, small and medium level Up-country Tamil entrepreneurs who represent the three town areas of Nuwara Eliya, Badulla and Hatton. The owner of the enterprise was considered as the head of each unit and 20 units were selected from each town area. The Business Registration Directories which are maintained under the Divisional Secretariat's offices of each area have been used as the sampling frame. At least twenty business owners in each town were selected using a random number sequence ${ }^{5}$. Most of the entrepreneurs in this region were males. A few of female entrepreneurs have been interviewed as a special sub-sample, as the issues are likely to be experienced somewhat differently by men and women. The study is limited to entrepreneurs who have been engaging in business for at least a year in order to understand the effect that networking has on their business. After building rapport through direct and indirect contacts with the business owners, personal interviews were conducted to extract information on their networking capacity. Duration of each interview was dependant on the satisfactory level of outcome of each event. Therefore, interviews with some of the respondents had to be conducted more than once with the respective interviewer. Gathering information on the (1) networking personality of each individual, (2) their embedded relations and (3) bonded connections to the external communities were expected as the major outcomes of those interviews.

Interviewing procedure was used as the key data generating technique of the Study. The interviewees were selected to the study sample randomly. The person who owns the business was considered as the key interviewee. However, additional details engendered from shop assistants within the ongoing interview process accounted purposively for further enhancement of the validity of data. The venue and time for the interviews were set by meeting or through telephone conversations with the business owners. In some occasions, the first visit itself was a successful interview.

Each interview was scheduled with the objective of covering the whole range of details related to the business of the particular respondent. The interviewing 
process was rather straightforward owing to the pre-arrangement of semistructuralized questionnaire. However, depending on the occasion and the individual, the interviewing procedure was flexible disregarding its order and basic framework. Therefore, the methodological flexibility gained more information in terms of "snowballing" data. Six major business-requires such as, consultancy, monetary support, external contacts, information, manual labour and loans have been highlighted at interviewing process and frequencies of their hits with selected networking relationships were counted. Microsoft Office-Excel 2007 software programme have been used for data tabulating and analysing purposes. In addition, ethnographic techniques has been employed infinitely analyse the quality of networking patterns of study group. Further, many outcomes of research have been diminished due to skimping-needs of the paper.

\section{Networking Patterns of Up-country Tamil Businesses}

There are several significant networking patterns that are followed by Upcountry Tamils as their basic mobility channels within the business sector. These networking patterns seem to be used for generating both social and fiscal capital. Kinship, caste, neighbourhood, and friendship relations are responsible for the configuration of their initial business networks. The strength in the level of kinship is determined at three levels in the order of primordial ties such as (1) nuclear family members, (2) extended family members, and (3) close relatives who reside among these embedded relations.

A married individual generally gets membership of two nuclear families: The family of orientation to which he/she was born, and the family of procreation built up by each person through their marriage. The family of orientation consists of ego, own brothers, sisters and parents. The procreation family consists of ego, spouse and own children. The members that belong to these two families have been considered as close relatives. The interactions among these family members are determined by the emotional ties shared by each other. Conceptually, if two or more generations live together, it is identified as an extended family. Nuclear family members are also automatically members of the extended family. Grandfather, grandmother, father, mother and their parallel brothers and sisters (married or unmarried) and grandchildren are regular members of an extended family.

The relatives who are living separately or dwelling in geographically remote areas due to marriage or the other reasons, and the relatives who belong to third or fourth circles of kinship patterns are regarded as the third category of the kinship structure. Father's and mother's brothers and sisters, their children and the people who come from different clans with marriage relations of their 
children are mainly included into this kinship group. Relationships with similar caste members or people who are believed to be members of the same caste are equal in the relationship with distant relatives. However, these primordial ties among relatives could be dependent on necessity in the business field. For instance, the association with relatives in the third or fourth steps of the kinship structure could go well beyond the ties with nuclear family members depending on the business needs.

Usually the traditional family has been considered a destructive institution in terms of business activities. However, we identify the family as a productive process in this study. Household production is determined by the production of goods and services by its own members for their own consumption by investing their own capital and their unpaid labour. Their service-satisfaction may be symbolically reflected in the emotional reactions of other family members. Goods and services such as child care, cleaning activities, security and accommodation are produced by the household for their own use (Ironmonger, 2001).

'Neighbourhood' is a determinant factor of geographical location of home or business place. Sustaining of neighbourhood relationships is dependent on the skills of each household member to deal with outsiders. Although one may live in a particular location for a long period, at times it may not result in building significant relationship with outsiders. On the other hand one may construct connections within a short while. This is the common experience of neighbourhood relations. Neighbourhood relationships may be more important than links with blood relatives living in distant areas. It could be highly dependent on the frequency of cooperative behaviour between each other. This situation is frequently stated in the statement such as "the people in close proximity are the only relatives in an immediate need". These valuable neighbours could be sometimes one's own relatives, caste members, religious and ethnic members or occasionally others who do not belong to any of the above categories.

On our field experience, the substance of friendship sometimes goes beyond both kinship and neighbourhood as it appears in inspecting the geographical factors of networking relations. The friendship relations of an individual could emerge with peer groups, similar gender groups, people who are attached to the same employment, groups having similar experiences or with people who could not be taken into any of the above categories. In general, though friendship relations encompass needs and occurrences of everyday life, it is also an important factor regarding establishment of businesses. Therefore these three-fold relationships such as caste/kinship, neighbourhood, and friendship are significant factors of entrepreneurial networking patterns amongst the Up- 
country Tamil community. The market maker who enters into the business world with these embedded relations may successfully accumulate social capital in different forms as the following:

- Motivating towards entrepreneurship

- Supporting to identify proper business places or providing such spaces which belong to them

- Making contacts and developing new relationships

- Providing business information

- Providing manual labour to build new shops, business stalls etc.

- Showing new orientations and occurrences

- Supplying capital by providing instruments, everyday-crediting without interest (kadan), and business-loans without interest

However, an innovative market maker who has a dynamic personality but who does not satisfy with the basic network in the surrounded environment has to look for new avenues in the business field. The majority of Up-land Tamil entrepreneurs depend on the initial forms of the network and they seem to be in favour of lagging in the same positions. This geographical movement can be stated as a "progressive action" at this stage. According to Cassion (2010), the entrepreneurs who have dynamic personalities are more likely to move from original locations and non entrepreneurs are stay. He further states "...This is particularly true of people brought up in isolated rural areas where there are few opportunities for profit. Such areas tend to lose their more entrepreneurial young people. Conversely, large cities tend to attract entrepreneurial young people" (Ibid). The same situation can be seen in the estate sector. The entrepreneur who handles business at plantation-based areas mainly targets one's own ethnic group as customers. The person who wishes to move-away from his basic ties to look for newer avenues and opportunities has to make several breakthroughs such as the following:

I. Geographical: From estate to town or bazaar

II. Trans-ethnic: From endogamy relations to exogamy relations

III. Trans-cultural: From native norms and values to 'new attitudes'

IV. Modernization: From traditional business to new trends

The entrepreneurs have to face several challenges in their geographical mobilizing from the plantation sector to a distant city or at least nearby town or bazaar. Given their economic background the acquisition of required facilities for this attempt is a difficult exercise. As the first step, the immigrant has to be away from accommodation that has been provided by the plantation administration on behalf of his service to the plantation. There would be little chance if he has other family members there who work for the estate 
proprietary. The next challenge will be finding a proper business space in a popular area or bazaar. New contacts with the 'others' are needed in this process to achieve newer goals. Since the entrepreneur is short of capital to purchase an appropriate business space, he has to look for external funds, loans or at least an increase in his current income. What usually could happen under these circumstances is that he may lease a shop on a monthly rental basis. The regular payment of the monthly rental is a must to maintain goodwill with the landlord.

After starting the business in a new location the entrepreneur is required to deal with uncertain groups of customers. Gaining familiarity with their anticipations, customs, attitudes and everyday needs is the next challenge. Moreover, he has to improve his skills and capabilities to serve an additional number of customers. Efficiency of service is important to maintain goodwill with the clientele. Consequently, the common experience of estate-bazaar migrants is the utmost selfless dedication they attach to their businesses. Sometimes, they are required to work the entire eighteen hours per day. Subsequently the entrepreneur has to find new ways of managing money, labour, instruments and service corresponding to the current environment. When he/she is gravitating towards the town or bazaar, he/she is required to mingle with the other ethnic groups. Consequently, he/she has to work mainly with Sinhala and Muslim ethnic groups and others according to the ethnic composition of Sri Lankan society. Therefore it is not only obligatory to familiarize with the new geographical location and people but also the need to be fluent in languages of these ethnic groups, particularly in Sinhalese.

Sometimes to struggle against the attitude of the people of the own community may be the hardest experience for a new entrepreneur. The making of money or accumulation wealth may not be a reason to receive good remarks from the society at the initial stages of establishing the business. Sometimes, businessminded persons could have been refused acceptance within peer groups. So many associate qualities such as "gluttony", "greed", "collector", "exploiter" to look down upon those who endeavour to build their fiscal consolidation. Often, it so happens that business minded people are not even popular within their own family members. They may reject him as an unhelpful person. Therefore, there may be many difficulties to be overcome for a beginner at the early stages.

The same people who helped him/her to start a business at the beginning may sometimes go against. The entrepreneurs are required to practice varied customs to protect themselves from evil spirits that might come from neighbours, envious relatives, or some customers who frequently come to the business place. These evil spirits can be visited in different forms such as evil 
eye or evil mouth. As a result of these beliefs, white magic which is practiced to avoid evil power can be seen in almost all Tamil business places. Hanging a chain in front of the shop which fixed with chilli and lemon, burning dried chilli in the fire, spreading turmeric water on the floor surrounding the shop, and blowing holy smoke over the business place are some of the practices used to seek protection from evil spirits. As a whole, these factors could suggest that the same bonded ties which helped them at the standing points of business, providing manual labour, consultancy and financial support may also result in an extra burden at a particular level. Therefore, the entrepreneur has to make a breakthrough with a "big decision" regarding the baseline network and traditional norms and values at the later stage.

Most probably the entrepreneur can use three options on the subject of norms and values in order to achieve business goals. The first option is the conservation of tradition. This may be less risky and less harmful to the family and other embedded relations. The benefits might be dependent on the consolidation of network ties. As the second option he/she can get a breakthrough by weakening, moderating or neutralizing traditional values (Figure 1). For instance, the entrepreneur can temporarily stop thinking about friends and close relatives justifying that: "although I lose these friends and relatives in this position, I would be able to help them after I become a reputed businessman" or "if I am being accused by these people at this stage, I will regain all dignity upon becoming a rich man". The third way of dealing with norms and values is attaining entrepreneurial goals by overwhelming all traditional customs and attitudes and then moving towards the new goal. This may be a highly risky action and future benefits also will be equivalent to the extent of risk.

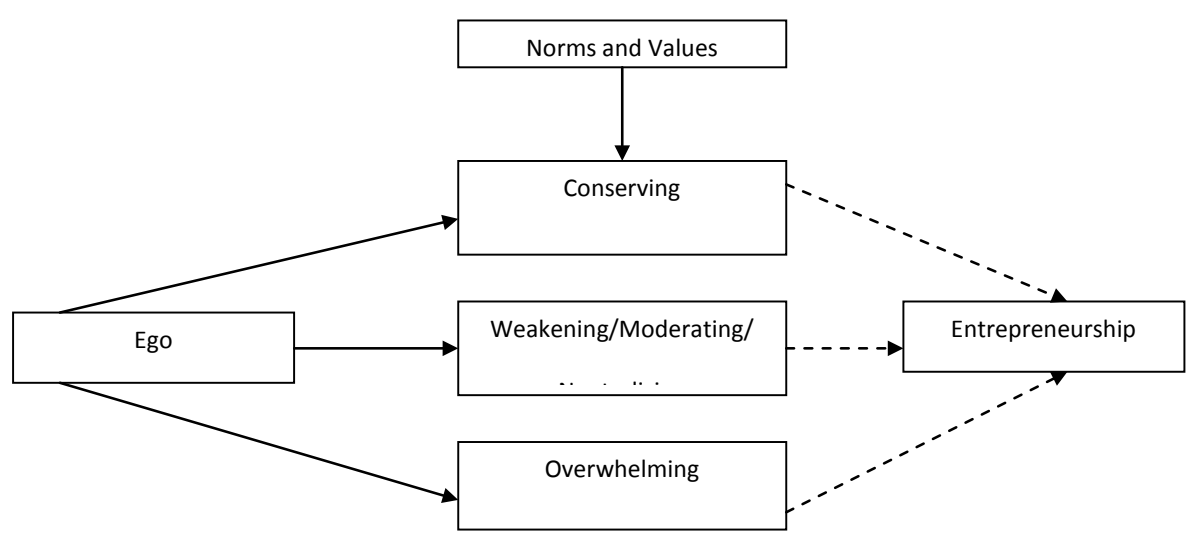

Figure 1: Hedging Norms and Values

The circumstance of hedging traditional norms and values may appear over 
the whole period of businesses. This struggle can be rather complicated at the initial stages. This mechanism can be acknowledged as a transformation from a particular set of ethics to a cross-cultural set of beliefs. In this sense, Up-country Tamil entrepreneurs are more tactical in integrating cross-cultural values and belief. It reflects their rituals and practices. The flexibility shown by Hinduism towards new trends affords opportunity. For instance, there is a space for the Buddha, Jesus Christ, and sometimes images of Mecca are seen among their pantheon of God Vishnu, Murugan, Shiva, Saraswathi and Sri Lakshmi within the sacred place in the shop or business premises.

Moreover, today "Siva Cafes" or "Siva Restaurants" has constructed a specific image among cafés and restaurant culture in Sri Lanka. In general use, the "Siva Café" offers Hindu vegetarian foods. Basically these types of cafes serve instant foods like Rotti, Paratha, Iddly, Thosai, Vadai, and their gravy such as Lentil curry, Sambar etc. These are known as totally animal proteinfree productions. Although there were only a few "Shiva Cafes" available in the main cities in the past, currently they are mushrooming in every part of the country due to the popularity of vegetarian food among all the ethnic groups.

The popularity of Siva Cafes is not common among non-vegetarian clients such as Muslims, Christians, Sinhalese and also some of the Hindus. As a result of the demand from non-vegetarians clientele their basic stand has been changing. At least 40 percent of Siva Cafes sell non-vegetarian foods according to our sample study. There is no restriction to meat consumption among Tamil entrepreneurs who changed their religion from Hinduism to Christianity. These characteristics are directly compatible with Wilkens' (1979) three-fold innovations: factor, material and market. Beef, the most restricted meat among the Hindus, is also not unusual in these cafes. Although these cafes are named 'Siva' according to the nature of food items, there is a tendency that they are gradually becoming multi-ethnic and multi-cultural. Currently chicken, mutton, pork, and beef are being added in addition to dhal, Sambar and others in these cafes as a result of adaptation to the new market condition.

Modernization has always been another significant factor in the enhancement of Tamil business in the recent decades. Traditional Tamil businesses had been dominated by their cultural needs. Currently modernization of businesses is seen in several aspects such as goods, technology and management (to state pungently "the shifting from the $V \bar{e} t t i{ }^{6}$ to the coat"). As has been stated earlier, the Up-country Tamil business originated by making a market, which focused inwards into their own community and it, characterized products suiting its own cultural needs such as beetle, tobacco, foodstuff such as bread, rice, spices etc. However, their selling items have modernized according to the demand of the multi-ethnic society in Sri Lanka. Technologically the Upcountry Tamil business places are also gradually acquiring modern equipments 
according to the economic and status level of each. For instance, normal calculators to computer are being steadily comprised into their everyday used items. Although, family members are still significant in the managerial sector, it clearly seems to be those vacancies are opening towards trained and knowledgeable outsiders with gradual growth of their businesses.

Within this structural and instrumental background, the Up-country Tamils have formed their entrepreneurial approaches into several specific patterns. Some patterns emerged directly utilizing positive ingredients of the cultural values and others were generated as a result of reaction to the everyday challenges of livelihood. Although it is possible to have some more networking patterns, this attempt is to develop a general idea about some prototypes that are likely to be the most frequent approaches of Up-country Tamil entrepreneurship as are the followings.

Pattern I, illustrates the form of market maker who is shifting his business from private space to public space. On the one hand, this is a geographical movement from the estate sector to a public location such as a town or bazaar. This movement causes oneself to untie from the plantation administrative system. The entrepreneur is freed to utilize public spaces for business purposes. On the other hand, this could be considered as moving from private relations to public relations (Figure 2). The entrepreneur handles his business at the initial stage using bonded relations with family members such as father, mother, brothers, sisters and sons and daughters. Sometimes cousins and nephews or some other relatives also might be the regular members of this network. Sometimes, it may be possible to see thicker reciprocity between several members within the family depending on the nature of the business purposes. Then the entrepreneur has to deal with the general public who are unfamiliar. After moving from the native place to a town or bazaar, he/she is required to bridge relations with other ethnic groups such as Sinhalese, Muslims and non-related Tamils who are direct and indirect stakeholders of the current business network.

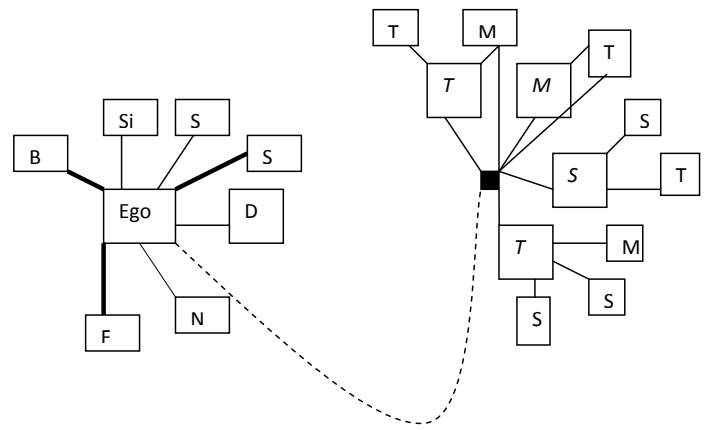

Figure 2: Moving from bonding to bridging 


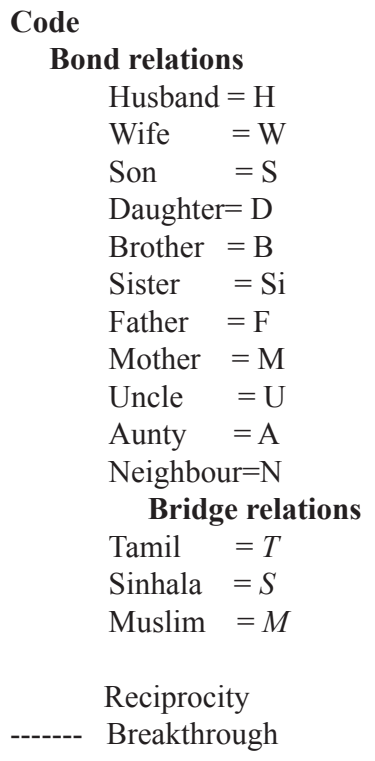

Sometimes, leaving or having a breakthrough from the basic network may be a risky decision, because the entrepreneur has to pay additional attention to maintain the business at a new location. The entrepreneur who is accustomed to obtain labour free of charge from the baseline network has to be transformed into the novel conditions. Often he has to bear an additional cost for maintenance purposes for hiring labour from alien locations. Therefore, the breakthrough period may be less profitable or comparatively backward (Lin 2001). However, networking with outsiders with trust developed on 'armlength relation' is a must to achieve considerable progress.

In accordance with pattern II which can be settled on the entrepreneurial mobility of Up-country Tamil community, the individual and his/her personal skills and capabilities may be the key persuasive factors. He/she has to move on his/her own without any family background. The business holder's grandparents may have come as immigrant estate workers in the early stages of Sri Lankan plantation economy. Most often they may not have had significant changes in their lives up to his father's generation. Everybody has been bonded to the employment of the plantation economy that rooted them for long into the circle of everyday life.

The entrepreneur who has a breakthrough from his traditional order is shifting to a shop as a shop assistant in a major city. A friend who he met accidentally helps him find the new occupation. Although this instantaneous friend had been a cornerstone of whole changes of his lifetime, this accidental friendship may very much be an occasional and vague connection. The entrepreneur who moved to new direction can be successful in accumulating material and 
human capital with his long term working experience as a shop assistant. Next he has another breakthrough in investing both material and human capital in a new business. The new and emerging entrepreneur receives considerable support from family members at the basic stages of the business. He has another breakthrough shifting his business from the estate to the town or bazaar. Thereafter, the entrepreneur continues a new business with secondary relations and with some business friends in the wholesale market in Colombo maintaining relations with the previous working place(s). Initial family support, however, is not obligatory. Sometimes several family members could be attached to the new business as an expert manager or an accountant and also as shop assistants.

There is a trend in the Up-country Tamil businesses to retain their business structures continuously without many changes for several generations. These types of business derive from their traditional occupational structure under the caste system. The respective father of these businessmen usually comes from poor village backgrounds in South India, similar to the majority of the Up-country Tamils. Although their ancestors emigrated from their native lands due to harsh conditions of drought and landlessness, they may claim some cultural capital derived from their ancestors. Goldsmiths and sweetmeat makers are prominent cases of this trend. For instance, in accordance with our sample test, four out of nine jewellery shop owners belong to Vishwa or Ashari ('Goldsmith' and 'Engineer') castes. Others too fit into parallel castes such as Chettiar, Kudiam, Naidu and Mukkulavar. They have directly come for business purposes aspiring to provide their services to their own community along traditional trading knowledge (cultural capital) or with a little material capital.

Usually these types of entrepreneurs have achieved an advanced class background and social status within their fellow groups. As a trade, jewellery production is a popular and well-paying business in South Asian societies. On the one hand, jewellery is a particular type of saving system in Tamil community. It is also highly profitable and the demand does not decrease economically and culturally. On the other hand, these forms of businesses help one to rise above the caste system and achieve a proper position in the social class hierarchy. Therefore, business holders are either reluctant or do not want to shift to another business field in terms of changing their traditional occupation. They may continue the same business with or without institutional and technological modernization. Mostly these businesses are inherited from father to son as a family business. As ancestral heritage, the next generation also support these businesses under the catchphrase "one day all this will be yours" (Cassion 2010). 
Pattern IV illustrates higher mobilization within generations of business families in terms of the nature of business characteristics. Traditionally, the entrepreneur has some business heritage within the family background, but it is not directly derived from the caste structure.

These styles of entrepreneurs could be representative of both ends of entrepreneurship in terms of its stability. When they start a new business without proper cultural or family background, they may not be able to gain expertise in a particular field. If somebody tries to be more innovative in a specific sector, there are enough spaces for him/her to be stable and make advancements within a short period. However, an entrepreneur who has a dynamic personality has more opportunities to expand his business within a vast area of the business field. They may not lag in the same position and easily react to the new trend of the market. Therefore, most of the entrepreneurs who follow this pattern have benefited from the "high risk-high profit" mechanism.

Pattern V reflects the direct influence of the economic globalization process at the micro-level in Sri Lankan families after 1970s. For instance, the decision taken by the Middle East oil producing countries (OPEC) to increase the price of petroleum caused a remarkable augmentation of their economy at the beginning of 1970s (Bal, 2003). Consequently, the gradual distribution of the national revenue among the people created a largely wealthy population over the region. Therefore, the employment opportunities increased, but the local population was inadequate to meet the labour requirement, and its inevitable consequence was the opening of the job market to the external world. These job opportunities were shared by neighbouring countries of the Middle East such as, Yemen, Sudan and Egypt, and later these opportunities were opened to the South and Southeast Asian countries mainly India, Pakistan, Bangladesh, Philippine, Sri Lanka and Thailand. This circumstance created an opportunity for such countries to export labour, as the Middle East countries became increasingly successful in accumulating a huge amount of capital by selling petroleum related products. The countries surrounding the Middle East benefited by acquiring a considerable amount of wealth through the provision of labour, and these foreign currencies that flowed to the labour supplying countries helped build up their own domestic economies over the past three decades (Elens \& Speckmann 1990; Samarasinghe 1998). This situation draws out an attractive functional sketch as a by-product of the globalization process, as the unintended consequences and long-term affects in the relevant countries are significant.

Sri Lanka is also an integral part of this process in several angles (Shaw 2008). Consequently the new situation had been an internal push factor not only for one ethnic group but all ethnic groups including the Up-country Tamil 
community to gain its benefits in terms of enhancement of their household incomes. Subordinated to this business networking pattern, some of the male family members of the Up-country Tamil community gained more benefits in accumulating capital to invest in their businesses. There is enough evidence to say that investing Middle East remittances sent by male partners of the Up-country Tamil community enriched their family-based micro businesses. They have built successful businesses using remittance sent by male partners working in the Middle East. One of the main reasons of their success may be due to the fact that their objective was to accumulate capital to invest in their joint ventures

Female labour migration to the Middle East is another significant aspect of the same story. A huge portion of women employees are working in Middle East countries attached to the blue-collar job market. They are mostly employed as domestic workers, garment factory workers and other similar occupations. Upcountry Tamil females who belonged to the lower level of the class hierarchy have also benefited from being attached to the immigrant labour force in the Middle East.

According to our experiences, female labour migration to the Middle East seems to be having a varied effect on aspirations. Frequently the migrant's socio-economic background determines the objectives of accumulation of extra capital. In proportion to their expectation levels, they can be classified into three basic scales. The first category can be accepted instantly as 'entrepreneurs'. They may probably be the owners of an existing micro or small-scale business. Or they might have an idea to begin self-employment. They have a greater capability to start a new business or develop current business with the accumulation an extra amount of capital. The second category may not stand for direct entrepreneurial purposes and sometimes this trend can easily be classified into non entrepreneurial roles. However, this type of economic motive may be more communitarian than the first category. Although this behaviour may not sound entrepreneurial, the long-term planning and aspirations of these persons may go beyond the first category. The Middle East immigrant women belonging to the third group demonstrate enough characteristics of non-entrepreneurial roles. They can be identified as "mere employees" and their family backgrounds also do not support significant changes of their current social life pattern. The remittances sent by these women labourers could possibly have been misused by their local family members.

The majority of the Middle East migrant women from the estate sector in Sri Lanka seem to belong to the second or third categories. However, according to our field research outcomes, a good number of Up-country Tamil females were 
found to belong to the first category in the entrepreneurial scale. A considerable number of family businesses have been benefited from the remittances sent by women who work as domestic workers in the Middle East.

Patten VII points out the economic function of the marriage tie and particularly the dowry system which has influenced the Up-country Tamil businesses. Dowry has been highlighted by feminists as a symbol of male dominance of the marriage circumstance (Anderson, 2003; Kodoth, 2005). However, the dowry system among the Up-country Tamil families could be identified as a form of 'economic cooperation' offered by female section to the newly married couple rather than a form of property or wealth to be paid by the bride's party to the groom or to the groom's family.

The dowry system is not a regular feature among the bottom level Up-country Tamil families. Mostly their dowry would be limited to jewellery belonging to the bride. However it could be a dominant factor with the upper levels of the class hierarchy. Estate workers seldom accumulate money for business purposes. When an individual needs to start his own business, he will be facing the problem of shortage of basic capital. Therefore the dowry may also be an appropriate opportunity for an estate worker who has a micro-level business or who has an idea to enter into the business sector.

Centre-periphery expansion is the most recent market making networking pattern of the Up-country Tamil business. This pattern tends to be popular in the comparatively remote areas in the estate sector. The market makers who established their medium-scale wholesale and retail shops in provincial centres have started opening their branches in the peripheries. The identification of new market directions tend to emerge through kinship and friendship networks. Usually the market maker suggests this to his relative or a friend to commence a small shop in his/her neighbourhood proximity and then the entrepreneur becomes the central person in performing the structural hole. He provides wholesale and retail goods including initial construction facilities to the peripheral agents. The key person of the network mostly uses own transport service to deliver goods to the outside agents. Sometimes this delivery service provided by their wholesale holder may be the only outside contact for these retailers. Therefore, delivery services play a crucial role in this type of business.

The remote setting of the estate accommodations and their infrastructural shortcomings is a general push factor for meeting the recruitment of dependent retail shops in these particular areas. The new entrepreneur, who identifies difficulties day by day, is motivated to start a micro business at the household level. The neighbourhood community obtains invaluable services from them 
to overcome their everyday life challenges. Most often, the wholesale traders based in the centres are keen to promote these new businesses. This reciprocal relationship may benefit the city-based traders to get hold of their service through peripheral agents in collecting household productions such as black pepper, arica-nuts, rubber raw materials, coffee etc. Therefore, this business relationships leads to a reduction in the gap between the rural and urban areas.

Although the retailers play a key role as market makers in the remote and local areas, their actual role is market taking from the wholesalers, and the manufacturers. As such, the retailers' role is significant as the local agents of the mass production market system. The retailer acts as a middleman or a facilitator between market makers and market takers. Therefore the retailer may be the decision maker of the remote localities (Petrovic et al., 2011). The person, who is engaged into this intermediate function more innovatively, may be identified as entrepreneurs at the local level. Although there is an assumption about an "age of global retailers" (ibid), we can expect subsidiarylevel market makers from remote areas in the developing regions.

\section{Reciprocity of Business Networks}

Reciprocity deals with personal or secondary relationship between two individuals or between an individual and social institutions. The key principle of reciprocity may be the human need and tendency to offer something back when something is received (Cote et al., 2006). This may depend on the interdependence of people and social institutions. Both parties the recipient and the donor mutually benefit from maintaining reciprocal relationship and these benefits could be either material or non-material. When somebody handles a business, he/she is obliged to maintain different types of reciprocity. Sometimes the strength of different relationships may be unequal to each other. Under this basic circumstance, this study has tried to measure the weightage of reciprocity between entrepreneurs and other individuals and institutions. All basic and secondary relationships between business holder and nine major categories such as nuclear family, close relatives, friends and neighbours, other relatives, media, transport services, staff members, monetary services, are summarized below.

Figure 1 shows the concise weightage denoted by each institution to the fulfilment of business goals. The nuclear family recording $38 \%$ carried the highest rate of involvement. Close relatives and friends and neighbours claimed the next most significant weightage indicating $16.6 \%$ cent and $12.8 \%$ cent. These figures strongly suggest that Up-country Tamil businesses are likely to be highly dependent on their basic networks. For Lazarsfed \& Merton (1954) these types of relationships are known as networking within value and status groups in the ordinary stages. Basically, ethnicity, class and 
caste, religion or other cultural believes are known as the determinant factors of value groups. Although other services and social organizations such as the media, transport services, regular staff members and monetary services are available, it is certain that they are comparatively less important. Despite some entrepreneurs having successfully moved towards the towns and bazaars overcoming geographical and cultural barriers, they still do not seem to trust the weaker ties.

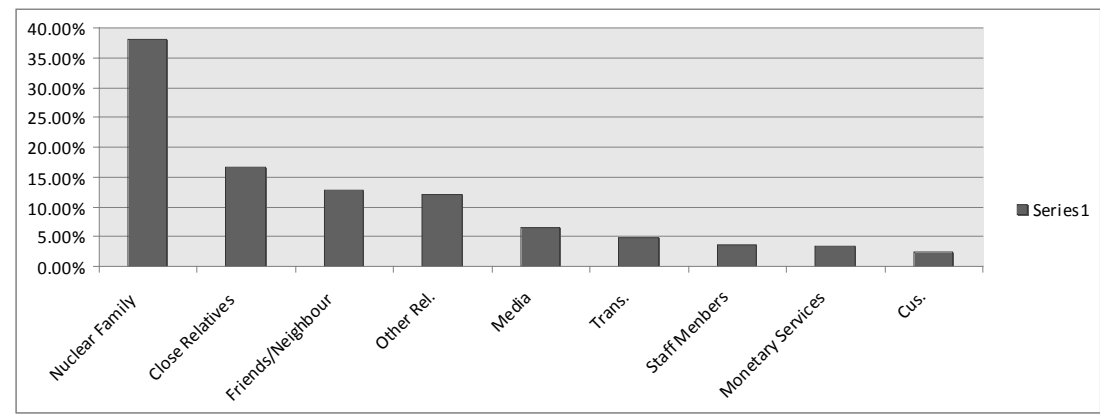

Figure 3 Overall summary at the weightage of business relationships Sources: Field reaserch

Table I represents personal reciprocity of traders with different sources in the fulfilment of six major entrepreneurial functions such as consultancy, monetary support, external contacts, information, manual labour, and loans with interest and without interest basis. The reciprocity of Tamil businesses has been measured with regard to 42 characteristics of personal contact. These personal relations may be in the form of face-to-face-relationships with people, things or social institutions. In the following table, these 42 characteristics of contacts have been classified under 9 major categories encompassing their quality from emotional relationships to secondary or tertiary contacts. The significance of contacts of each individual belonging to each category from nuclear family to other secondary relations with six variables has been measured. 'Consultancy' service is just a non-profitable service, which carries new ideas for the enhancement of businesses. This basically occurs as informal discussions. However, these informal consultancy services may help to introduce innovations that predict market conditions, prevent possible threats and unnecessary risks. As can be seen in Table 1, the wife is significant in consultancy as well as other services. Considered to the other consultancy services, the Up-country Tamil businesses seem to be highly dependent on nuclear family members. According to Fukuyama (1994) these types of business are likely to be immature in terms of network building. Business relations could benefit more when constructing relations with weak ties or outsiders. 
Table 1 Descriptive significance of personal relationship in each business function

\begin{tabular}{|c|c|c|c|c|c|c|c|}
\hline & Consultancy & $\begin{array}{l}\text { Monetary } \\
\text { Support }\end{array}$ & $\begin{array}{l}\text { External } \\
\text { Contacts }\end{array}$ & $\begin{array}{l}\text { Business } \\
\text { Information }\end{array}$ & $\begin{array}{l}\text { Manual } \\
\text { Labour }\end{array}$ & $\begin{array}{l}\text { Loan } \\
\text { without } \\
\text { Interest }\end{array}$ & $\begin{array}{l}\text { Loan } \\
\text { with } \\
\text { Interest }\end{array}$ \\
\hline Business Fri. & $49 * *$ & 5 & $31 *$ & $57 * * *$ & 3 & $28^{*}$ & 0 \\
\hline Husband/Wife & $54 * * *$ & $23^{*}$ & 18 & 13 & $43^{* *}$ & 0 & 0 \\
\hline Friends & $37 * *$ & 7 & 5 & 5 & $35^{* *}$ & 18 & 0 \\
\hline Brother & & 19 & 0 & 6 & $34 * *$ & 10 & 0 \\
\hline Father & $37 * *$ & $27 *$ & 1 & 7 & 19 & 6 & 0 \\
\hline Neigh. & 1 & 3 & $20 *$ & 1 & $48^{* * *}$ & 6 & 6 \\
\hline Sister & $28^{*}$ & 12 & 7 & 4 & 19 & 8 & 0 \\
\hline Bro. in Law & 15 & 4 & $22 *$ & 6 & $22 *$ & 4 & 0 \\
\hline Bajar & 0 & 0 & $26^{*}$ & $34^{*}$ & 0 & 0 & 0 \\
\hline Son & 13 & 6 & & 3 & $32 *$ & 1 & 0 \\
\hline Uncle & 12 & 8 & 13 & 7 & 12 & 3 & 0 \\
\hline Delivery & 0 & 0 & $20^{*}$ & $24 *$ & 0 & 7 & 0 \\
\hline Son in Law & 12 & 3 & 12 & 2 & 15 & 2 & 0 \\
\hline Daughter & 18 & 3 & 1 & 1 & $22 *$ & 0 & 0 \\
\hline Mother & 8 & 7 & 0 & 0 & $26^{*}$ & 1 & 0 \\
\hline Manager & 13 & 0 & 6 & 16 & 0 & 0 & 0 \\
\hline Customer & 9 & 0 & 11 & 15 & 0 & 0 & 0 \\
\hline Bank. Pub & 0 & 0 & 0 & 0 & 0 & 0 & $22 *$ \\
\hline Inf.Econ.Grp & 6 & 0 & 0 & 4 & 0 & 10 & 1 \\
\hline Bank Pvt & 0 & 0 & 0 & 2 & 0 & 0 & 18 \\
\hline TV & 1 & 0 & 0 & 18 & 0 & 0 & 0 \\
\hline Shop. Ass. & 7 & 0 & 1 & 5 & 4 & 0 & 0 \\
\hline Sis. In law & 1 & 0 & 10 & 2 & 3 & 0 & 0 \\
\hline Dau. In law & 1 & 0 & 4 & 4 & 4 & 2 & 0 \\
\hline Grad. Fa & 7 & 3 & 0 & 0 & 2 & 1 & 0 \\
\hline Aunt & 3 & 2 & 0 & 0 & 6 & 1 & 0 \\
\hline NGO & 7 & 0 & 0 & 2 & 0 & 0 & 1 \\
\hline News pap & 0 & 0 & 0 & 10 & 0 & 0 & 0 \\
\hline Politi. & 1 & 3 & 3 & 0 & 0 & 0 & 0 \\
\hline Radio & 3 & 0 & 0 & 4 & 0 & 0 & 0 \\
\hline Step Br & 3 & 0 & 0 & 0 & 2 & 0 & 0 \\
\hline Step Sr & 1 & 0 & 0 & 0 & 4 & 0 & 0 \\
\hline Grad Dau & 0 & 0 & 0 & 1 & 3 & 0 & 0 \\
\hline Grand. Mo & 2 & 1 & 0 & 0 & 1 & 0 & 0 \\
\hline Grand son & 0 & 0 & 0 & 0 & 1 & 0 & 0 \\
\hline Savant & 0 & 0 & 0 & 0 & 1 & 0 & 0 \\
\hline Internet & 0 & 0 & 0 & 1 & 0 & 0 & 0 \\
\hline
\end{tabular}

External contacts may be the most important factor in terms of making links to the other structural holes. Connecting to external networks, business friends and the bajar ${ }^{7}$ seem to be noteworthy among other variables of the table. Neighbours can also be taken as another main source of receiving contact with outsiders. Brother in-law, son in-law (same kinship identity in different relation to the interviewee), and delivery services have been considered as the next important sources of external contacts. Son in-law or the brother inlaw is definitely important close relatives coming from a different clan. He is the focal point of two different kinship groups. If he is coming from another business family, his role will be indispensable in the context.

The new trend of the market, more profitable goods, anticipation of customers and many other aspects represent business information. According to the order of significance, business friends, media (all forms), bajar, transport or delivery services, managerial staff, customer and monetary services tend to be more significant in terms of receiving such business information. As with every other function, the informal networking with business friends seems highly 
important in receiving business information. The information that comes from the media tends to be received mainly by the upper level business owners. Television has been on the top of all other media. The delivery or transport services may be the most important information source for the business holders in remote areas. Some micro and small-scale shops in the periphery can entirely dependent on delivery services. According to field experience, some wholesale traders in cities and town areas maintain regular network relationship with small retail traders in the periphery providing goods and free delivery services. Consequently, the delivery services may be the only link between the town or bazaar and remote rural areas. Moreover, the bajar has been considered significantly as an important source of business information. Although there is no particular person or an institution called the bajar, the symbolic value of the term as a source of information should be investigated.

The "business bajar" seems to be a functional structure which gains reciprocal benefit to each other. The business holder who handles a business in a particular locality is required to be integrated into the system to continue his/ her business. Wittingly or unwittingly he or she has a role to play in a particular bajar within an identified geographical territory. Therefore, the concept of bajar is a little complicated and relies on a broader sense than a general social group or a formal social organization. Nobody can go against the decisions of the bajar. There is no particular person who is accountable for decisions of the bajar. However, everybody is obliged to respect it. Sometimes it may be the collective consciousness of the entire bajar. For instance, the fruit sellers who sell the same kind of fruit along a particular side street may sell their goods for similar prizes. If somebody introduces a new idea which results in goods at cheaper rates, it is certainly going to be harmful for the peers. Therefore, people who go against the bajar's decisions may get isolated or some other harder measures may be taken against them. Moreover, the bajar conceptually characterizes informal social capital. The trust on weak ties, social security, unexpected external intrusions is recovered by bajar.

Therefore, bajar is an important concept to distinguish 'mainstream' and 'outsider' traditions of business networking. The upper level market, or the business handled by large-scale market makers are usually secured in the capitalistic economic structure. All kinds of commercial agencies such as banks, insurance companies, government policy system, government police bureau and many other organizations are structurally created to provide necessary facilities and security to the concurrent market system. These agencies are looking forward to provide hedging facilities to avoid taking unnecessary risk at fluctuating market prices, to supply distress loan during market liquidation, to recover any kind of losses occurred as a result of theft, fire or any other disasters to the reputed traders. However, there is no such formal protection 
to the bottom line business holders from the system. They are constantly vulnerable at the circumstance of market competition. Sometimes bottom line retailers are required to find options to overcome everyday market challenges. Therefore, we can recognize the bajar as a bottom line latent functional action aroused against the dominant market structure.

According to the order of variables, Table 1 shows that neighbours, spouses, friends and brothers are the most predominant characters providing manual labour. The figures also illustrates that all the other members of the extended family have also displayed at least some trend of volunteer services for businesses of family members. Manual labour may sometimes be the only exchangeable possessions which can be obtained as a volunteer service, while the physical awareness may be the only wealth which is available as a capital in a bottom-line community. In contrast, manual labour support seems to be the most frequent reciprocal relation among other variables. Moreover, Table 1 has demonstrated that Up-country Tamil businesses are still highly dependent on family-based or self-owned basic capital. Their trust on banks or reciprocity with other financial agents is little developed. However, often they receive loans without interests from business friends, general friends and other family members. There is a slight reciprocity with informal economic groups too (IEGs) in receiving non-interest based business loans. However, this source of finance seems to be less significant. Most entrepreneurs draw loans for interest from private and public banks only. Comparatively public banks have indicated marginal lofty relationships with entrepreneurs. As a whole, the programmes which have been launched by private and public monetary services for entrepreneurship development in the plantation sector seem to be attractive only among a very small segment of the business community.

\section{Conclusions}

This study has demonstrated the entrepreneurial mobility of the bottom line of the Up-country Tamil community that seems to be quite different from the main stream business community. Although the self-exploitation is a common experience of any successful businessman, the dedication to one's own business by a bottom level Up-country Tamil entrepreneur seems far greater than the upper level. There are several factors that have been observed to affect their mobilizing from the traditional occupations to the business sector. The emergence of many vacancies for blue-collar and less attractive jobs in the towns and cities created to the dependant capitalistic economy in the post-colonial period pulled them towards urban areas. Particularly the unemployed young men have been dragged by this vacuum mostly as porters, shop assistants, and similar occupations of these dependent metropolises. In the meantime, the increasing unemployment has caused deterioration in the 
plantation economy and the demand for the vacuum of less attractive trade such as collecting waste items seem the major motive for the emergence a little traditional business network within the bottom level of the Up-country Tamil community. The long term working experiences, which have been achieved from working in shops, hotels or similar places in surrounding towns and bazaars, and micro-scale social capital accumulated within nuclear families, are responsible for building their initial business structures. This sub-cultural business pattern is responsible for the building of outsider or the little traditional entrepreneurial action.

The study has also considerably delved into unpacking networking patterns followed by the Tamil market makers who are detached from their traditional occupations. Usually, we do not see this development of business network belonging to Up-country Tamil community as a spontaneous consequence of structural organization. It has arisen from long-term circumstances that manipulated, maintained and reproduced in the market system. Although they belong to a geographically and socially isolated community, the Upcountry Tamils are also gradually being integrated into this inevitable mode of production. The new market makers have to overcome many hardships and community barriers to satisfy entrepreneurial goals. Since they do not have accumulated material, symbolic and social capital as good as reputed mainstream business communities do, they have to be capable of accumulating micro-scale material and non-material capital that are dispersed over the close proximity within their neighbourhood. The innovators who wish to widen their business network have to release themselves from dependency at the basic-level of social ties. Moving from bonded to bridging relationships is not a smooth and spontaneous circumstance; long-term tolerability, patience and dedication are required for the progress.

\section{End Notes}

1. The homophily is a concept coined by Lazarsfeld and Merton in 1954. Its etymology of term come from homo $=$ self and philia $=$ love (Currarini et al., 2008)

2. Hoselitz (1951), attempted to figure out the earliest uses and meaning of the term entrepreneurship. He found three definitions of the word 'entrepreneurship' in a French dictionary published in 1889; the general meaning of those words simply refer to a person who is active, who gets things done (Spengler \& William 1960). He further addressed the English equivalents of the word 'entrepreneur' as it was understood in the seventeenth and early eighteenth centuries. The most common English 
word similar to the French entrepreneur was the word "undertaker" and sometimes "adventurer". The second term was well known, from the fifteenth century with the meaning of "merchant adventurers" and it also was applied to Irish land speculators, and other entrepreneurs in farming drainage projects and similar occupations over the seventeenth century (ibid). Even in the current period, there is no complete and commonly accepted definition on it, for example, Bogaert \& Das defined it as "Entrepreneurship is an 'in' thing” (1988). Schumpeter (1950) tries to define entrepreneur as "a person who is willing and able to convert a new idea or invention into successful innovation”. Knight [1979], Duru (2011), and Drucker (1985) identified 'risk taking' as distinctive characteristics of an entrepreneur; "The behaviour of the entrepreneur reflects a kind of person willing to put his or her career and financial security on the line and take risks in the name of an idea, spending much time as well as capital on an uncertain venture". Although these attempts were successfully reached to the targets from their own perceptions, they were not successful in explaining its dynamism and action direction.

3. Marginality is generally used to describe and analyse socio-cultural, political and economic spheres. International geographical Union (IGU), defined marginality as, "The temporary state of having been put aside of living in relative isolation, at the edge of a system (cultural, social, political or economic), ... in mind, when one excludes certain domains or phenomena from one's thinking because they do not correspond to the mainstream philosophy" (quoted in Gurung \& Corlemair 2005). Sommers uses a holistic approach to define marginality; emphasizing comparative backwardness of a given society in terms of economic, political and social well being. "Socio-economic marginality is a condition of socio-spatial structure and process in which components of society and space in a territorial unit are observed to lag behind an expected level of performance in economic, political and social well being compared with average condition in the territory as a whole" (Sommers et al., 1999; Gurung \& Colemair 2005).

4. Wilken (1979:) states:

...Hence, marginals are likely to play entrepreneurial roles under opposite conditions than are actors from the societal mainstream. The legitimacy of entrepreneurship will influence which of these two potential sources of entrepreneurship will be predominant in a society. In situations in which entrepreneurial legitimacy is low, mainstream actors will be attracted to the non-entrepreneurial roles, and entrepreneurial roles will be relegated to marginals. But in situation in which entrepreneurial legitimacy is high, mainstream actors will use the entrepreneurial role as a mobility channel, 
and marginals will have to find other roles as means of mobility. This later situation is characteristic of some racial and ethnic minorities.

5. Though I initially planned to study the selected sample of 60 from each town area, the attempt was unsuccessful in making appointments with some of them who fitted into the sample even after numerous and labourious attempts. Then I chose the next Tamil business place situated close to the previous selection. Sometimes I was able to interview the exact person who was initially in the random sample with a long stay in the research field, and consequently the number of interviews was extended up to 76 .

6. Vetti or vettidothi is a traditional or cultural dressing worn by men during feast, festival or official occasions, mainly in India.

7. The concept of "Bajar" directly derives from the Persian word "Bazaar" (Turkish pazar, Hindi bajar, Greek pazari) which means the "place of prize' or generally merchandize street. However, the lower middle-class and bottom line business community in Sri Lanka use it in a broader sense rather than the general meaning of 'bazaar'. For instance, under-world gangs, illegal businesses such as illicit liquor, making prostitution and many other pathological social organizations are indirect components of the term bajar.

\section{References}

Adhikari, B. (2001). Literature review on the economics of common property Resources - Project Report for NRSP Project R 7858. York: University of York.

Apesteguia, J., Frank, P., \& Rigaud, M. (2006). The Role of Rivalry:Public Good Versus Common-Pool Resources. Journal of Conflict Resolution, $50(2), 646-663$.

Apestequim, J., \& Maier, R. (2006). The Role of Rivelry:Public good versus Common-poll Resources. Journal of Conflict Resolution, 50(1), 646-663.

Arrow, K., Solow, R., Portney, P., E.E, L., Radner, R., \& Schuman, H. (1993). Report of the NOAA panel Contingent Valuation. 58(10), 4601-4614.

Beito, D, \& Smith, B. (1990). The Formation of Urban Insfrastructure through Nongovernment planing: The private places of St. Louis, 1869-1920. Journal of Urban History, 16(3), 263-303. 
Benson, B. (1994). Are public Goods Really Common Pools? Consideration of the Evaluation of policing and Highways in England. Economic Inquiry, 32(2), 249-227.

Bhattarai, M., Sakthivadival, \& Hussain, I. (2006). Irrigation Impact on Income Inequalities and Poversty. Colombo: International Water Management Institute (IWMI).

Board of Tourism Industry in Malaysia. (2012). Market Research Report. Kuala Lumpur: Malaysian Tourism Bord.

Boon Chui, C. T., Rahim, F. A., \& Hassan, F. H. (2010). Exploring Tourist Experiencescape and servicscape at Taman Negara National Park in Malaysia. International Journal of Trade, Economics and Finance, 1(1), 28-31.

Bromley, D. (1991). Environment and Economy: Property Rights and Public Policy. Oxford: Oxford University Press.

Cameron, T. (1998). A New Paradigm for Valuating Non-Market goods Using Refrendum Data. Journal of Environmental Economic and Management, 15(1), 355-379.

Cassion, Mark (2010). Entrepreneurship: Theory, Network, History (Ed.). Cheltenham: Edward Elgar Publishing Ltd.

Cote, Rochele R.; Wellman, Barry (2006). It's Not Who You Know, It's How You Know Them: Who Exchanges What With Whom. Social Networks. Vol. 29, No. 3 (July 2007). Canada: University of Toronto - Department of Sociology. Pp. 405-429.

Cowen, T. (1992). Public Goods and Market Failure: . New Brunswick N.J: Transactions Publication.

Currarini, Sergio; Matthew, O; Jackson, Paolo Pin (2008). An Economic Model of Friendship: Homophily Minorities and Segregation. (January 2007, Revised July 29, 2008). (Online Open Access).

Dahan, H. M., Ahmad, N., \& Ho, c. S. (2010). Crisis Management at Taman Negara National Park, Kuala Tahan, Pahang, Malaysia. International Journal of Trade,Economics and Finance, 1(1), 24-27.

Easter, K., Becker, N., \& Tsur, Y. (1997). "Economic Machanism for managing WaterResources:Pricing,Permits and Market". in A.K Biswas (ed.)Water Resource Invironmental Palnning, Management and Development. New York: McGraw-Hill. 
Ecotourism Society. (1998). Ecotourism Statistical Fact sheet: Generlal Tourrism Statistics. Washington DC: Ecotourism Society.

Foldvary, F. (1994). Public Goods and Private Communities: The market Provisions of Social Services . Aldershot, England: Edward Elgar.

Fukuyama, F. (1999). The Grate Disruption: Human Nature and the Reconstitution of Social Order. New-York: Free Press.

Grima, A., \& Berkes, F. (1998). Natural Resources: ccss, Rights-to-use and Management, Linking Social and Ecological System. Cambridge: Cambridge University Press

Gunathilaka, H., Chen, J., Pattanak, S., \& Chde, K. (2007). Good practices for Estimating Reliable williness-to-pay value in the water supply and sanitation sector- ERD technical notes series, No 23. Phillipines: Asian Development Bank, Economic and Research Department.

Gurung, Ghana S.; Michael, Colemair 2005. Marginality: Concepts and Their Limitations, IP6 Working Paper No. 4. Zurich: Development Study Group- University of Zurich.

Hair Jr, J., William , C., Barry, J., \& Rolph, E. (2010). Multivariate Data Analysis (Seventh Edition). New Jersey: Pearson.

Hanemann, W. (1984). Welfare Evaluations in Contingent Valuation Experiments with Discreate Responses. Americal Journal of Agricultural Economics, 66(2), 332-41.

Hanna, S., \& Munasingha, M. (1995). An Introduction to Property Rights and the Environment: Social and Ecological Isseus. Washington D.C: International Institute of Ecological Economics and The World Bank.

Hoselitz, Bert F. 1951. The Early History of Entrepreneurial Theory. Explorations in Entrepreneurial History No. 3. New York: AMS Press. Pp. 193-220.

Ironmonger, Duncan (2001). Household Production and the Household Economy. Melbourne: University of Melbourne, Department of Economics.

Johansson, R. (2000). Pricing Irrigation Water: A literature Survey. Washington DC: World Bank.

Joseph F, H., Black, W., Barry, J., \& Rolph E, A. (2010). Multivariate Data Analysis (Seventh Edition). Pearson Prentice Hall. 
Knight K. (1967). "A Descriptive Model of the Intra-firm Innovation Process". Journal of Business of the University of Chicago. Vol.40. Chicago. Chicago University Press.

Lin, Nan (2001). Social Capital: A Theory of Social Structure and Action. Cambridge: Cambridge University Press.

Marris, P. and Somerset A., (1971). The African Entrepreneur: A Study of Entrepreneurship in Kenya. New York, Africana.

McClelland, D.C. \& D. G. Winter, 1971. Motivating Economic Achievement. New York. Free Press.

Ministry of Science Technology and the Environment. (2010). Assessment of Biological Diversity in Malaysia: Contry Study of Biological Diversity. Kuala Lumpur: MOSTE.

Ministry of Science Technology and the Environment. (2010). Assessment of biological diversity in Malaysia: Country study of biological diversity. Kuala Lumpur: MOSTE.

Montgomery, M., \& Bean , R. (1999). Market Failure, Government Failure, and the Private Supply Public Goods: The Case of Climate-Controlled Walkway Network. Public Choice, 99, 403-437.

Morgan, M. (2007). We are not the Barmy Army: Reflections on the sports tourist experiences. International Journal of Tourism Research, 9(5), 361372 .

Ostrom E, Grandner, R., \& Walker, J. (1994). Neither Market nor states:Linking Tranformation Processin collective action arenas. Cambridge: Cambrudge University Press.

Ostrom, E. (2002). Common-Pool Resources and Institutions:Toward a Revised Theory. Center for the Study of Population and Environment Change,Indiana University.

Othman, N. A., Anwar, N. M., \& Kain, L. (2010). Sustainability Analysis: Various Ipact on Taman Negara, pahang, malaysia. Journal of Tourism,Hospitality \& Culnary Arts, 3(2), 67-80.

Petrovic, Misha; Hamilton, Gary H; Benjamin, Senauer (2011). Retailers as Market Makers: How Retailers are Reshaping the Global Economy. Oxford: Oxford University Press. 
Samdin, Z. (2008). Willingness to Pay in Taman Negara: A Contingent Valuation Method. International Journal of Economic and Management, 2(1), 81-94.

Samdin, Z. (2008). Willingness to Pay in Taman Negara: A Contingent Valuation Method. International Journal of Economic and Management, 2(1), 81-94.

Sefton, M., \& Steimberg, R. (1996). Reward Structure in public good Experiments. Journal of Public Eonomics, 60(1), 263-287.

Sell, J., \& Son, Y. (1997). Comparing public goods with Common-Pool Resources: Three experiments. Social Psychology Quartely, 60(2), 118137.

The International Ecotourism Society. (2007, Feb 12). Ecotourism Fact sheet. Retrieved March 03, 2012, from http:// international ecotourism society.

The International, E. (2006, Auguest 24). Ecotourism Fact Sheet. Retrieved June 2012.07.08, 2012, from Web articles net: http://www.ecotourism fact sheet

Varughess, J. (1999). Village Bureaucrats and Forest in Nepal: Desiging Governmance for Complex Resources, PhD Dissertation. Washiton: Indiana University Press.

Walker, J., \& Gardner, R. (1992). Probabilistic Destruction of Common- Pool Resources: Experiment Evidence. Economic Journal, 102(2), 212-234.

Weaver, D. (2008). Ecotourism. Melborn: John \& Wiley and Sons.

Wedgwood, A., \& Sansom, K. (2003). Willing-to-Pay Surveys: Streamlined Approach. Loughborough University. U.K: Water Engineering \& Development Centre.

Willinger, M., \& Ziegelmeyer, A. (1999). Farming and Cooperation in Public Good Game: An experiment with an interior solution. Economic Letters, 65(1), 323-328. 